\title{
The Effect of Yoga Exercise on Reducing Blood Pressure among Elderly with Hypertension : A systematic review
}

\author{
Bhakti Permana, Linlin Lindayani*, Agus Hendra, Lia Juniarni
}

Sekolah Tinggi Ilmu Keperawatan PPNI Jawa Barat

*Corresponding author: linlinlindayani@gmail.com

\section{ARTICLE INFO \\ HOW TO CITED: \\ Permana, B., Lindayani, L., Hendra, A \& Juniarni, L (2020). The Effect of Yoga Exercise on Reducing Blood Pressure among Elderly with Hypertension : A Systematic Review. Jurnal Pendidikan Keperawatan Indonesia. 6(2), p. $163-170$ \\ DOI: \\ 10.17509/jpki.v6i2.25083}

ARTICLE HISTORY:

Received

May 31, 2020

Revised

August 23, 2020

Accepted

September 01, 2020

Published

December 15, 2020

\begin{abstract}
ABSTRAK
Hypertension is the most commonly encountered problems experienced by the elderly with sometimes unknown cause. One effort to lower blood pressure in the elderly is to provide yoga exercises, where yoga exercises can stimulate endorphin hormone expenditure. The purpose of review was to determine the effectiveness of yoga exercises for decreasing blood pressure in the elderly. An initial search for articles was done on Google Scholar and PubMed. Studies obtained about exercise therapy for hypertension elderly have 4,560 articles / journals but only 5 articles meet the search criteria. According to the search results, yoga exercises can reduce blood pressure in the elderly. Besides, it is also very important to be applied as a non-pharmacological therapy for the elderly who have a medical history of hypertension. It is expected that health professionals can recommend this as a therapy for lowering blood pressure in the elderly.
\end{abstract}

Keywords: elderly, yoga exercises, blood pressure

\begin{abstract}
ABSTRAK
Hipertensi adalah masalah yang paling sering ditemui yang dialami oleh lansia dengan penyebab yang terkadang tidak diketahui. Salah satu upaya menurunkan tekanan darah pada lansia adalah dengan memberikan senam yoga, dimana senam yoga dapat merangsang pengeluaran hormon endorphin. Tujuan review adalah untuk mengetahui keefektifan senam yoga dalam menurunkan tekanan darah pada lansia. Pencarian awal untuk artikel dilakukan di Google Scholar dan PubMed. Studi tentang terapi senam lansia hipertensi didapatkan 4.560 artikel / jurnal tetapi hanya 5 artikel yang memenuhi kriteria pencarian. Menurut hasil pencarian, senam yoga dapat menurunkan tekanan darah pada lansia. Disamping itu juga sangat penting diterapkan sebagai terapi non farmakologi bagi lansia yang memiliki riwayat kesehatan hipertensi. Diharapkan tenaga kesehatan dapat merekomendasikan hal ini sebagai terapi penurunan tekanan darah pada lansia.
\end{abstract}

Kata kunci: lansia, senam yoga, tekanan darah

\section{INTRODUCTION}

The elderly is at high risk for degenerative diseases such as coronary heart disease (CHD), hypertension, diabetes mellitus, rheumatism, and cancer. One of the diseases that is often experienced by the elderly is hypertension
(Hendarti, E\& Hidayah, 2018). Data from the World Health Organization (WHO) in 2015 showed that around 1.13 billion people in the world have hypertension, meaning that 1 in 3 people in the world is diagnosed with hypertension (Oparil et al., 2018). The number of people with hypertension 
continues to increase every year; it is estimated that in 2025 there will be 1.5 billion people who are affected by hypertension and every year 9.4 million people will die from hypertension and its complications (WHO, 2019). The incidence of hypertension in the elderly in Indonesia for ages $55-64$ years is $55.2 \%$, aged $65-74$ years is $63.2 \%$ and $69.5 \%$ for ages above 75 years (Riskesdas, 2018). The prevalence of hypertension based on characteristics was $36.9 \%$ of women and $31.3 \%$ of men. From the prevalence of hypertension of $34.1 \%$ both male and female it is known that as much as $8.8 \%$ were diagnosed with hypertension and $13.3 \%$ of people diagnosed with hypertension did not take medication and $32.3 \%$ did not take medication regularly. The reasons for hypertension sufferers do not take medication are because hypertension sufferers feel healthy $(59.8 \%)$, irregular visits to healthcare facilities $(31.3 \%)$, taking traditional medicine (14.5\%), using other therapies $(12.5 \%)$, forgetting to take medicine (11.5\%), unable to buy drugs $(8.1 \%)$, there are side effects of drugs (4.5\%), and hypertension medications are not available at the health care centers (2\%) (Riskesdas, 2018).

Hypertension in the elderly is a disease where the upper limit blood pressure (systole) is more than $140 \mathrm{mmHg}$ and the lower limit blood pressure (diastole) is more than $90 \mathrm{mmHg}$ (Chopra \& Ram, 2019; Dwija Yasa, I., Azis, A., \& Widastra, 2017). Factors of hypertension can be divided into 2 groups: factors that can be changed, namely, obesity, smoking stress, exercise, excessive alcohol consumption, excess salt consumption and hyperlipidemia (Hendarti, E\& Hidayah, 2018; Kaboré et al., 2017) and irreversible risk factors consisting of gender, heredity, and age (Hendarti, E\& Hidayah, 2018). Increased age will cause some physiological changes, in the elderly there is an increase in peripheral resistance and sympathetic activity. Peripheral resistance is the resistance of blood vessels (especially arterioles) to blood flow (McEvoy et al., 2020). This resistance is mainly influenced by the radius of the blood vessel and blood viscosity. Meanwhile, increased sympathetic activity causes arteriolar vasoconstriction, where these nerve fibers supply the smooth muscle of arterioles throughout the body except in the brain. Blood pressure will increase after the age of 45-55 years, the arterial wall will experience thickening by the accumulation of collagen in the muscle layer so that the blood vessels will gradually become stiff (Setiawan, M. B., Kusumawati, P, 2014).

Efforts to manage hypertension can done with non-pharmacological treatment alternative to pharmacological treatment. Handling pharmacology itself using antihypertensive drugs. Pharmacologically, it is usually considered expensive by the community so that nonpharmacological treatment can be an alternative that can be done. One of them is by living a healthy lifestyle. Some of the recommended healthy lifestyles are to maintain body weight in normal conditions, regulate eating patterns by consuming low salt foods and increase intake of vegetables and fruits, reduce alcohol consumption, control stress and emotions, stop smoking, check for pressure regular blood pressure and increase exercise or physical activity (Soenarta, Arieska Ann., Erwinanto, Mumpuni, A. S.., Barrack, R., Lukito, A. A., Hersunarti, N. Pratikto, 2015).

According to (Sukmawati, 2019) that one way to control hypertension in the elderly is to routinely do yoga exercises because Yoga is proven to reduce levels of $b$-endorphin four to five times in the blood. Yoga exercises can stimulate endorphin hormone expenditure. Endorphin is a neuropeptide that produces the body in a relaxed / calm condition. Endorphins are produced in the brain and spinal cord. This hormone can function as a natural sedative produced by the brain that reduces high blood pressure. Previous researchers also revealed that there were differences in the results of blood pressure measurements before and after yoga exercises were given to changes in blood pressure in the elderly with a significant value (Hendarti, E\& Hidayah, 2018). This study is in line with research conducted by Yasa in 2017 which revealed that yoga exercises are one of the nonpharmacological therapies that are effectively carried out to overcome hypertension in the 
elderly. Therefore, based on this background, researchers are interested in conducting review on the effect of yoga exercises on reducing blood pressure in the elderly. The PICO was Population (elderly with hypertension), Intervention (yoga exercise), Comparison (no compassion), Outcome (decrease blood pressure). Thus, out PICO question was "In elderly with hypertension, does yoga exercise effectively reduce blood pressure?'.

\section{METHODS}

This study is a systematic review of the existing literature to evaluate subjective responses after the application of yoga exercise to decrease blood pressure in the elderly.

\section{Search Strategy}

The search strategy aims to find articles that have been published. Data from this review literature was obtained through an online search process. The search is done through Google Scholar and PubMed. The keywords used are a combination of yoga, exercise, therapy, hypertension, AND elderly. The search focused on journals that use Yoga exercises to reduce blood pressure in elderly hypertension. The search limited to English and Indonesian languages, published from 2015 to 2020 , human participant, clinical trial, and search for studies conducted in elderly patients with hypertension. The inclusion criteria for screening article was article should be:

1) Population, including elderly with hypertension. 2) Intervention was yoga exercise. 3) Comparison was with or without control group no compassion). 4) Outcome was decrease blood pressure.

\section{Screening Articles}

Article screening is carried out through the initial title and then abstract screening is carried out to identify which articles have the potential to meet the desired criteria. After that a review of all articles considered significant at initial screening was conducted. Additional articles not found in the initial literature search were obtained by reviewing references in the study. Two reviewers reviewed each abstract based on inclusion criteria. The first reviewer conducted an examination of all the titles and abstracts of the aim was to avoid repeating the article. Separately, the second reviewer assessed the sample titles and abstracts according to the same criteria to be chosen. Furthermore, the two reviewers agreed on which articles met the inclusion criteria.

\section{Data Extraction}

Each article is processed data by making a summary of each article which includes, author, year, country of origin of the study, type of study, sample (including the number of samples and inclusion criteria), intervention procedure, results, and limitations of the study.

\section{Assessment Quality of Study}

Assessment of the quality of each article is carried out using the standard format of The Critical Appraisals Skill Program (CASP), which is already in Indonesian. The criteria used to evaluate whether each study is of good quality and a minimum risk of bias consists of three components, namely whether the results of the study are valid, what are the results, will the research results help locally. There is a total of 11 checklist items that are used to do the assessment with answer choices yes / no reported.

\section{RESULTS \\ Searching results}

From the search results conducted through Google Scholar and PubMed. A number of journals were obtained by using a combination of keywords therapy exercise for elderly hypertension. Then as many as 4560 journals were obtained using the keyword combination yoga for hypertension, and as many as 75 journals were obtained using a combination of keywords. So that a total of only 5 articles that meet all search criteria. From the 5 articles, 4 were obtained using pre-experimental research designs with one group pre-test and posttest and 1 using a randomized parallel-arm random control with the number of samples in the range of 30-60. The population of 5 articles on average at the age of $60-80$ years, all journals said that the data collection was done by measuring blood 
pressure first before being given an intervention then after being given an intervention blood pressure measurement were taken. And interventions carried out namely (Sukmawati, 2019) 6 times in 2 weeks, according to (Patil et al., 2014) carried out for 6 days for 3 months, according to (Dhameja et al., 2013) carried out for 42 days and according to (Dwija Yasa, I., Azis, A., \& Widastra, 2017) carried out twice a week for four weeks, the first is that the patient is told to fill out informed consent, then do blood measurements first, then do yoga exercises (Figure 1).

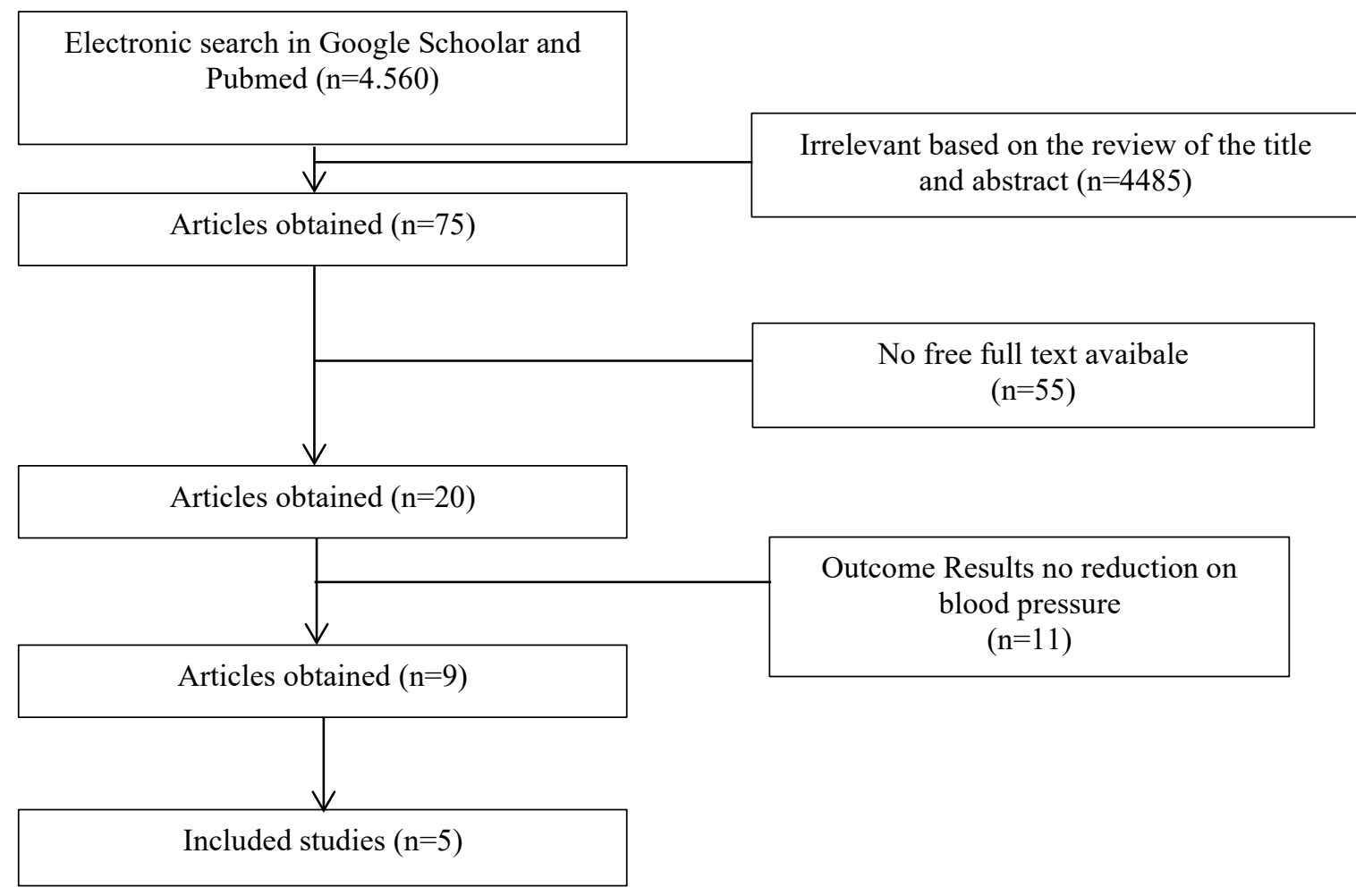

Figure 1. Flow diagram

\section{Results of studies' quality assessment}

In assessing the quality of articles, the findings of the 5 articles are stated to have good quality, where all articles have a CASP value of $90 \%$. Overall, this article has weaknesses. All included studies were not 'blind' because before the research was conducted respondents were informed of the research procedure first.

\section{Main Finding}

From the 5 articles, 4 were obtained using pre-experimental research designs with one group pre-test and post-test and 1 using a randomized parallel-arm random control with the number of samples in the range of 30-60. Population of 5 articles on average at the age of 60-80 years, all journals said data collection was done by measuring blood pressure first before being given an intervention then after being given an intervention a blood pressure measurement was carried out. The results showed that there was significant blood pressure reduction of $10 \mathrm{mmHg}$ systolic or $5 \mathrm{mmHg}$ diastolic after yoga exercises. According to Dr. Susatawati G Patil (2014), were conducted for 6 days for 3 months(Patil et al., 2014), according to Kanupriya Dhameja (2013) (Dhameja et al., 2013). for 42 days and according to I Dewa Gede Dwija Yasa, (2017) conducted twice a week for four weeks (Dwija Yasa, I., Azis, A., \& Widastra, 2017). 
Permana, B., Lindayani, L., Hendra, A \& Juniarni, L | The Effect of Yoga Exercise on Reducing Blood Pressure among ...

Table 1. Summary of included studies $(n=5)$

\begin{tabular}{|c|c|c|c|c|c|c|}
\hline $\begin{array}{c}\text { Author / } \\
\text { Year }\end{array}$ & Objective & Sample & Design & Intervention & Results & $\begin{array}{l}\text { CASP } \\
\text { score }\end{array}$ \\
\hline $\begin{array}{l}\text { Sukmawati \& } \\
\text { Isnaeni (2019) } \\
\text { (Sukmawati, } \\
\text { 2019) }\end{array}$ & $\begin{array}{l}\text { Aims to } \\
\text { determine the } \\
\text { effect of yoga } \\
\text { exercises on } \\
\text { blood pressure } \\
\text { in the elderly } \\
\text { with } \\
\text { hypertension. }\end{array}$ & $\begin{array}{l}\text { Elderly aged } \\
60-85 \text { years } \\
\text { who suffer from } \\
\text { hypertension. }\end{array}$ & $\begin{array}{l}\text { Quantitative } \\
\text { research with } \\
\text { Pre-Experiment } \\
\text { research } \\
\text { methods }\end{array}$ & $\begin{array}{l}\text { The } \\
\text { intervention } \\
\text { given was yoga } \\
\text { exercises given } \\
6 \text { times in } 2 \\
\text { weeks to the } \\
\text { intervention } \\
\text { group. }\end{array}$ & $\begin{array}{l}\text { Systolic and diastolic blood } \\
\text { pressure before yoga exercise } \\
\text { had an average of } 155 \mathrm{mmHg} \\
\text { and } 96.25 \mathrm{mmHg} \text {. Whereas } \\
\text { systolic and diastolic blood } \\
\text { pressure after yoga exercises } \\
\text { have a mean of } 122 \mathrm{mmHg} \text { and } \\
81.25 \mathrm{mmHg} \text {. Difference } \\
\text { obtained in systolic decreased } \\
\text { by } 33 \mathrm{mmHg} \text { and diastolic } \\
\text { decreased by } 15 \text { mmHg. The } \\
\text { results of Wilcoxon statistical } \\
\text { analysis showed a p-value of } \\
\text { systolic blood pressure of } 0,000 \\
\text { and diastolic blood pressure of } \\
0,000 \text { with a significance level } \\
<0.05 \text {. }\end{array}$ & 10 \\
\hline $\begin{array}{l}\text { Hendarti \& } \\
\text { Hidayah (2018) } \\
\text { (Hendarti, E\& } \\
\text { Hidayah, 2018) }\end{array}$ & $\begin{array}{l}\text { Analyzing the } \\
\text { effect of yoga } \\
\text { exercises on } \\
\text { changes in } \\
\text { blood pressure } \\
\text { in the elderly } \\
\text { who experience } \\
\text { hypertension }\end{array}$ & $\begin{array}{l}50 \text { elderly who } \\
\text { have } \\
\text { hypertension }\end{array}$ & $\begin{array}{l}\text { using a pre- } \\
\text { experimental } \\
\text { one group pre- } \\
\text { test post-test } \\
\text { design study } \\
\text { design, } 50 \\
\text { samples were } \\
\text { selected using } \\
\text { simple random } \\
\text { sampling } \\
\text { technique. }\end{array}$ & $\begin{array}{l}\text { The } \\
\text { intervention } \\
\text { given was yoga } \\
\text { exercises with } \\
\text { blood pressure } \\
\text { measurements } \\
\text { before and after } \\
\text { the } \\
\text { administration } \\
\text { of the } \\
\text { intervention. }\end{array}$ & $\begin{array}{l}\text { There are differences in the } \\
\text { results of blood pressure } \\
\text { measurements before and after } \\
\text { yoga exercises given to } \\
\text { changes in blood pressure in } \\
\text { the elderly with a significant } \\
\text { value. }\end{array}$ & 10 \\
\hline $\begin{array}{l}\text { Yasa, Azis, \& } \\
\text { Widastra } \\
(2017) \text { (Dwija } \\
\text { Yasa, I., Azis, } \\
\text { A., \& Widastra, } \\
\text { 2017) }\end{array}$ & $\begin{array}{l}\text { Aims to } \\
\text { determine the } \\
\text { effect of hatha } \\
\text { yoga on blood } \\
\text { pressure in } \\
\text { blood with } \\
\text { hypertension. }\end{array}$ & $\begin{array}{l}30 \text { elderly } \\
\text { people aged } \geq \\
60 \text { years that } \\
\text { meet the } \\
\text { inclusion } \\
\text { criteria and } \\
\text { exclusion and } \\
\text { signed } \\
\text { informed } \\
\text { consent sheet. }\end{array}$ & $\begin{array}{l}\text { Using a quasi- } \\
\text { experimental } \\
\text { design with a } \\
\text { research design } \\
\text { pre-test and } \\
\text { post-test one } \\
\text { group design, } \\
\text { which was } \\
\text { carried out on } \\
30 \text { samples } \\
\text { selected with } \\
\text { purposive } \\
\text { sampling } \\
\text { technique }\end{array}$ & $\begin{array}{l}\text { Blood pressure } \\
\text { measured } \\
\text { before being } \\
\text { given an } \\
\text { intervention on } \\
\text { first meeting } \\
\text { and after being } \\
\text { given } \\
\text { intervention at } \\
\text { the 8th meeting. }\end{array}$ & $\begin{array}{l}\text { There are mean differences } \\
\text { significant at the pre-test and } \\
\text { post-test systolic blood pressure } \\
\text { in the respondent that is equal } \\
\text { to } 9.03 \mathrm{mmHg}(\mathrm{p}=0,000 \\
<0.05) \text {. } \\
\text { While the diastolic blood } \\
\text { pressure of respondents there } \\
\text { are differences in the mean } \\
\text { significant between pre-test and } \\
\text { post-test that is } 4,274 \text { mmHg (p } \\
=0,000>0,05 \text { ). The results } \\
\text { showed that mean systolic and } \\
\text { post-test blood pressure } \\
\text { diastolic is } 146.97 \text { / } 86.27 \\
\text { mmHg. } \\
\text { This decrease in blood pressure } \\
\text { can be caused by the practice of } \\
\text { hatha yoga which is given to } \\
\text { respondents. }\end{array}$ & 10 \\
\hline $\begin{array}{l}\text { Dhameja, et al } \\
\text { (2013) } \\
\text { (Dhameja et al., } \\
\text { 2013) }\end{array}$ & $\begin{array}{l}\text { Analyzing the } \\
\text { effects of yoga } \\
\text { on patients who } \\
\text { experience } \\
\text { hypertension }\end{array}$ & $\begin{array}{l}60 \text { elderly who } \\
\text { have } \\
\text { hypertension }\end{array}$ & $\begin{array}{l}\text { using a pre- } \\
\text { experimental } \\
\text { one group pre- } \\
\text { test posttest } \\
\text { design research } \\
\text { design, } 60 \\
\text { samples were } \\
\text { selected with a } \\
\text { simple total } \\
\text { sampling } \\
\text { technique. }\end{array}$ & $\begin{array}{l}\text { The } \\
\text { intervention } \\
\text { given was yoga } \\
\text { exercises with } \\
\text { blood pressure } \\
\text { measurement } \\
\text { before and after } \\
\text { giving the } \\
\text { intervention. }\end{array}$ & $\begin{array}{l}\text { There are differences in the } \\
\text { results of blood pressure } \\
\text { measurements before and after } \\
\text { yoga exercises given to } \\
\text { changes in blood pressure in } \\
\text { the elderly with a significant } \\
\text { value. }\end{array}$ & 10 \\
\hline
\end{tabular}




\begin{tabular}{|c|c|c|c|c|c|c|}
\hline $\begin{array}{l}\text { Patil (2014) } \\
\text { (Patil et al., } \\
\text { 2014) }\end{array}$ & $\begin{array}{l}\text { The purpose of } \\
\text { this study was } \\
\text { to investigate } \\
\text { the effects of } \\
\text { yoga on } \\
\text { oxidative stress } \\
\text { in the elderly } \\
\text { with Grade-1 } \\
\text { hypertension. }\end{array}$ & $\begin{array}{l}\text { Elderly aged } \\
60-80 \text { years } \\
\text { who suffer from } \\
\text { Grade-1 } \\
\text { hypertension. }\end{array}$ & $\begin{array}{l}\text { This study is an } \\
\text { open parallel } \\
\text { arm } \\
\text { randomized } \\
\text { control study. }\end{array}$ & $\begin{array}{l}\text { Interventions } \\
\text { provided in the } \\
\text { form of yoga } \\
\text { conducted for } 3 \\
\text { months, carried } \\
\text { out six days a } \\
\text { week walking } \\
\text { casually at } 6 \text { to } \\
7 \text { o'clock in the } \\
\text { morning. }\end{array}$ & $\begin{array}{l}\text { There are differences in the } \\
\text { results of blood pressure } \\
\text { measurements before and after } \\
\text { yoga exercises given to } \\
\text { changes in blood pressure in } \\
\text { the elderly with a significant } \\
\text { value }\end{array}$ & 10 \\
\hline
\end{tabular}

\section{DISCUSSION}

From the five journals above, yoga exercises have been shown to reduce high blood pressure, an average decrease in systolic 15 $\mathrm{MmHg}$ and diastolic $10 \mathrm{mmHg}$. The intervention was carried out for 8 times in 2 weeks with 50 60 minutes. The difference in results from the 5 articles is when giving yoga exercise interventions based on research conducted by Sukmawati (Sukmawati, 2019) that yoga practice is given that is for 1 month every week there are $2 \mathrm{x}$ meetings to do yoga exercises. From the research conducted by Hendarti (Hendarti, E\& Hidayah, 2018) yoga exercises were given for 4 weeks, every week there was $1 \mathrm{x}$ meeting to do yoga exercises. From research conducted by I Dewa Gede Dwija Yasa, Abdul Azis, I Made Widastra (Dwija Yasa, I., Azis, A., \& Widastra, 2017) that yoga practice is given that is for $6 \mathrm{x}$ in 2 weeks. From research conducted by Dr. Satish G Patil (Patil et al., 2014) that the practice of yoga is given every day for 42 days. From research conducted by Kanuya Dhameja, (Dhameja et al., 2013) that the practice of yoga is given for 42 days. From the results of these 5 articles, there are differences due to differences in the amount of time the practice is given and the number of times the training is given.

Yoga can reduce blood pressure by doing yoga movements can reduce pro-inflammatory adipokines, proteins released by fat tissue. Yoga also increases anti-inflammatory adipokines in high metabolic adults, so blood pressure becomes normal. Because yoga can manage metabolism well. Metabolic is a condition of increased blood pressure, excess fat, high blood sugar and excess body fat in the area around the waist (Landhiani,
2018). Yoga has physiological effects on muscle strength, an increase in several body positions which are believed to affect the autonomic nervous system and endocrine glands which regulate internal functions including heart rate and hormone production. Yoga can make $25 \%$ of patients with high blood pressure stop taking high blood pressure-lowering drugs and $35 \%$ begin to reduce it (Dinata, 2015).

Yoga is a combination of breathing and body exercises. Most positions such as lifting legs, stretching shoulders, and rotating the spine can help lower blood pressure. By doing yoga two to three times a week can reduce blood pressure from $133 / 80$ to $130 / 77$. Yoga keeps muscles flexible and supple, for example like stretching yoga regularly, stretching can help keep arteries supple and naturally reduce blood pressure. According to a study by the American Journal of Physiology, Yoga conducted in the elderly over the age of 40 years, the patient's ability to sit and reach tests can be used to assess arterial flexibility. A simple test for touching your toes from a sitting position can show the level of arterial stiffness, which often occurs in cardiovascular disease. Stretching exercises can trigger physiological reactions that slow the hardening of the arteries based on age (Samiaji, 2019).

Factors that can affect the physiological factors because Yoga plays an important role in increasing oxygen intake into the brain, eliminating fatigue, increasing energy and vitality, increasing flexibility and stamina, stimulating hormonal glands in the body and making it stable. Yoga movements can also facilitate blood circulation (Dinata, 2015). Literature review carried out previously is a study 
conducted by (Oktavia, D., \& Indriati, 2012), explaining that yoga practice can reduce blood pressure in the elderly with hypertension at the "Pelkris" Nursing Home and the Semarang Nursing Home. In a previous study conducted by Devi Oktavia in 2011, it was proven that after doing yoga exercises in the elderly with hypertension, it was found that most of the respondents experienced a decrease in systolic blood pressure after the intervention of yoga exercises for 3 times a week.

The implication is that Yoga exercises which are carried out programmatically and routinely can be one of the non-pharmacological therapies in reducing hemodynamic conditions, especially in blood pressure, pulse and breathing in the elderly who suffer from hypertension. Therefore, yoga exercises can be an appropriate choice of physical exercise and can be applied independently without creating risks at this age. The implication of nursing practice is that it is necessary to carry out further research on adaptation to other body systems such as immunology and others in the elderly to yoga exercises so that the benefits of the body in the elderly are increasingly apparent.

\section{REFERENCES}

Chopra, H. K., \& Ram, C. V. S. (2019). Recent Guidelines for Hypertension. Circulation Research, 124(7), 984-986. https://doi.org/ 10.1161/CIRCRESAHA.119.314789

Dhameja, K., Singh, S., Mustafa, M. D., Singh, K. P., Banerjee, B. D., Agarwal, M., \& Ahmed, R. S. (2013). Therapeutic effect of yoga in patients with hypertension with reference to GST gene polymorphism. Journal of Alternative and Complementary Medicine (New York, N.Y.), 19(3), 243-249. https:// doi.org/10.1089/acm.2011.0908

Dinata, W. (2015). Menurunkan tekanan darap pada lansia dengan yoga. Jurnal Olahraga Prestasi, 11(2).

Dwija Yasa, I., Azis, A., \& Widastra, I. (2017).

\section{CONCLUSION}

Based on the analysis of the journal that has been presented in the previous chapter, it can be concluded that yoga exercises have a significant effect on reducing the decrease in blood pressure in the elderly. Yoga exercises can be an effort to improve blood pressure balance in the elderly. Yoga exercises can be safely performed in the elderly by combining breathing exercises, relaxation and the structure of gentle movements. The basics of movement in yoga exercises can reduce blood pressure in the elderly so that the elderly can maintain their physical strength to perform daily activities to the fullest in their abilities. Yoga exercises can be used as a non-pharmacological method to improve efforts to manage hypertension in the elderly as an additional therapy besides pharmacotherapy without side effects. The results of this study are recommended for use as a non-pharmacological therapy in an effort to treat hypertension safely and without side effects. The results of this study are recommended to be used as further development of research in this field and to prepare clinical guidelines for using therapy in the social care center.

Penerapan hatha yoga dapat menurnkan tekanan darah pada lansia dengan hipertensi. Coping: Community of Publishing In Nursing, 5(1), 19-25.

Hendarti, E\& Hidayah, A. (2018). Pemberian Terapi Senam Yoga Terhadap Perubahan Tekanan Darah Pada Lansia Yang Mengalami Hipertensi Di Kabupaten Sidoarjo. Prosiding Seminar Nasional Unimus, vol.1.

Kaboré, J., Metzger, M., Helmer, C., Berr, C., Tzourio, C., Drueke, T. B., Massy, Z. A., \& Stengel, B. (2017). Hypertension Control, Apparent Treatment Resistance, and Outcomes in the Elderly Population With Chronic Kidney Disease. Kidney International Reports, 2(2), 180-191. https://doi.org/10.1016/j.ekir.2016.10.006 
Landhiani, J. (2018). Alami Tekanan Darah Tinggi, Sembuhkan dengan Yoga yuk!

McEvoy, J. W., Daya, N., Rahman, F., Hoogeveen, R. C., Blumenthal, R. S., Shah, A. M., Ballantyne, C. M., Coresh, J., \& Selvin, E. (2020). Association of Isolated Diastolic Hypertension as Defined by the 2017 ACC/AHA Blood Pressure Guideline With Incident Cardiovascular Outcomes. JAMA, 323(4), 329-338. https://doi.org/10.1001/ jama.2019.21402

Oktavia, D., \& Indriati, P. A. (2012). Pengaruh Latihan Yoga Terhadap Penurunan Tekanan Darah Pada Lanjut Usia (Lansia) Di Panti Wreda Pengayoman "Pelkris" Dan Panti Wreda Omega Semarang. Jurnal Ilmu Keperawatan Dan Kebidanan, 1(2).

Oparil, S., Acelajado, M. C., Bakris, G. L., Berlowitz, D. R., Cífková, R., Dominiczak, A. F., Grassi, G., Jordan, J., Poulter, N. R., Rodgers, A., \& Whelton, P. K. (2018). Hypertension. Nature Reviews. Disease Primers, 4, 18014. https://doi.org/10.1038/ nrdp.2018.14

Patil, S. G., Dhanakshirur, G. B., Aithala, M. R., Naregal, G., \& Das, K. K. (2014). Effect of yoga on oxidative stress in elderly with grade-I hypertension: a randomized controlled study. Journal of Clinical and Diagnostic Research : JCDR, 8(7), BC04-7.
https://doi.org/10.7860/JCDR/2014/9498.4 586

Riskesdas. (2018). BAsic health research. Ministry of Health; Jakarta.

Samiaji, L. (2019). Apakah Yoga Dapat Menurunkan Tekanan Darah Penderita Darah Tinggi. Available at http://promkes. kemkes.go.id/olahraga-yoga-bisamenurunkan-tekanan-darah-tinggi

Setiawan, M. B., Kusumawati, P, D. (2014). Pengaruh penyuluhan kesehatan tentang pengobatan non farmakologi terhadap perilaku penderita hipertensi dalam melaksanakan pengobatan non farmakologi di Puskesmas Sampung Kabupaten Ponorogo. Jurnal Strada, 4(2), 42-51.

Soenarta, Arieska Ann., Erwinanto, Mumpuni, A. S.., Barrack, R., Lukito, A. A., Hersunarti, N. Pratikto, R. . (2015). Pedoman Tatalaksana Hipertensi Pada Penyakit Kardiovaskular. Pedoman Tatalaksana Hipertensi Pada Penyakit Kardiovaskuler. Perhimpunan Dokter Spesialis Kardiovaskuler Indonesia, 1st ed., $V$.

Sukmawati, R. (2019). Pengaruh Senam Yoga Terhadap Tekanan Darah Pada Lansia Penderita Hipertensi Di Wilayah Dusun Kwarasan Nogotirto Sleman Yogyakarta. Unisa Digital Library.

WHO. (2019). World Hypertension Day 2019. 